\title{
A Landscape Indicator Approach to the Identification and Articulation of the Ecological Consequences of Land Cover Change in the Chesapeake Bay Watershed, 1970-2000
}

\section{Background}

The advancement of geographic science in the area of land surface status and trends and land cover change is at the core of the current geographic scientific research of the U.S. Geological Survey (USGS) (McMahon and others, 2005). Perhaps the least developed or articulated aspects of USGS land change science have been the identification and analysis of the ecological consequences of land cover change.

Changes in land use and land cover significantly affect the ability of ecosystems to provide essential ecological goods and services, which, in turn, affect the economic, public health, and social benefits that these ecosystems provide. One of the great scientific challenges for geographic science is to understand and calibrate the effects of land use and land cover change and the complex interaction between human and biotic systems at a variety of natural, geographic, and political scales.

Understanding the dynamics of land surface change requires an increased understanding of the complex nature of human-environmental systems and will require a suite of scientific tools that include traditional geographic data and analysis methods, such as remote sensing and geographic information systems (GIS), as well as innovative approaches to understanding the dynamics of complex systems. One such approach that has gained much recent scientific attention is the landscape indicator, or landscape assessment, approach, which has been developed with the emergence of the science of landscape ecology.

\section{A Landscape Indicator Approach}

Due to the increasing need to monitor ecosystem health and because of the traditionally high costs associated with fieldbased monitoring, alternatives to, and adaptations of, the traditional monitoring approach have been developed using highresolution remotely sensed data, standard geographic data, and derivative products. Termed the "landscape indicator approach," this alternative applies a combination of concepts from landscape ecology, hydrology, and geography in conjunction with remotely sensed and other spatial data and GIS technology to the assessment of landscape and ecological conditions (O'Neill

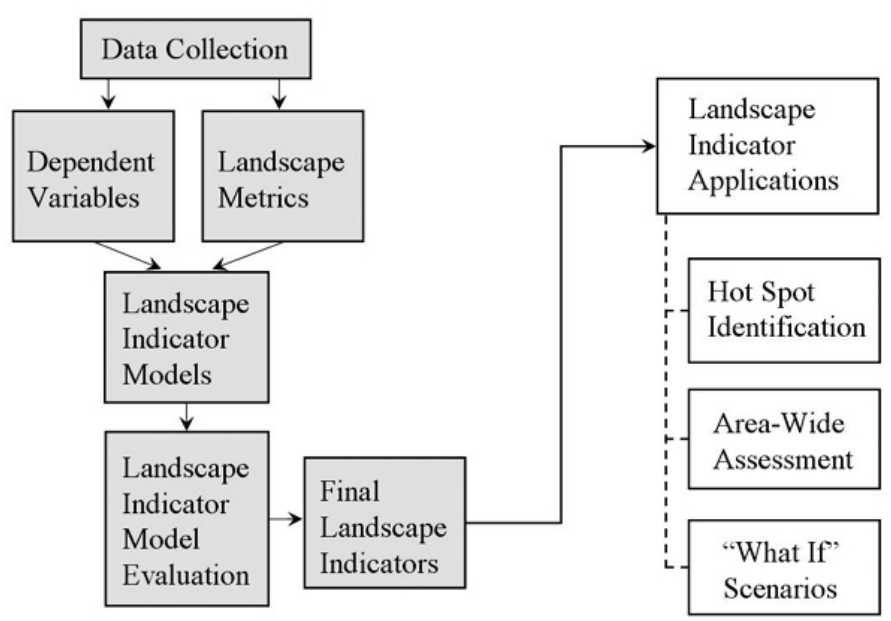

Figure 1. The conceptual components and processing sequence of the general landscape indicator model. From Pitchford and others (2000).

and others, 1997; Jones and others, 2000; Pitchford and others, 2000). Figure 1 shows the concept design of a landscape indicator project.

The landscape indicator approach relies on the following:

- Geographic analysis of spatially explicit patterns of ecological characteristics (for example, riparian zones near streams) to interpret ecological conditions

- Concepts from landscape ecology relating changes in landscape patterns to changes in ecological processes

- Hierarchy theory that analyzes the consequences of landscape change on ecosystems at multiple scales

- Spatially explicit digital data and maps of biophysical and cultural characteristics and human use to interpret landscape patterns relative to ecological conditions

- Inclusion of humans as part of the environment 
Typically a landscape indicator project for an area starts with the acquisition or development of a series of base geographic data in a GIS format. These data typically include the following:

- Land use and land cover data in a raster format representing one or more time periods

- Stream and hydrology data in a vector format

- Road and transportation data in a vector format

- Normalized Difference Vegetation Index (NDVI) derived from satellite imagery

- A digital elevation model

- Data from field sampling or a monitoring network, such as USGS streamgages

- Any other GIS data layers targeted for a specific ecological consequence

These data layers are then used to compute a series of landscape metrics and landscape indicators for each of the analytical units in the study area, which typically are watersheds. Landscape metrics are defined here as numerical values based on a single GIS data layer, such as forest area or total road miles. Landscape indicators are numerical values that are derived from two or more data layers and some analytical operation, such as agriculture on steep slopes or riparian forest buffers.

\section{The Chesapeake Bay Watershed}

The need to understand ecosystem stresses at the landscape level is great in the Chesapeake Bay watershed. The Nation's largest estuary, the Chesapeake Bay has been degraded, in part because of the doubling of the human population between 1950 and 2000; results of the human population increase include degradation of water quality, loss of habitat, and declines in populations of critical biological communities (Phillips, 2005). Rapid changes in land use in the watershed (fig. 2) have affected waters flowing into the bay.

Since the mid-1980s, the Chesapeake Bay Program (CBP), a multi-agency partnership that includes the U.S. Department of the Interior and the U.S. Environmental Protection Agency, has worked to restore the bay ecosystem. However, after over 20 years of restoration activities by the CBP, there is growing concern that ecological conditions in the bay and its watershed have not significantly improved. There is an acute need for enhanced science to better document the reasons for the lack of significant ecosystem improvement and to assess the types and potential locations of restoration activities that will provide the greatest benefit to achieve ecologically sustainable development in the bay watershed (Phillips, 2005).

Jones, Neale, Wade, and others (2001) compared nitrogen yields (fig. 3) and bird habitat changes between 1970 and 1990 in the mid-Atlantic region; the area includes the Chesapeake Bay watershed. They demonstrated the usefulness of the landscape indicator approach.
Landscape indicators and landscape metrics represent a new analytical approach that could be especially appropriate for the identification and analysis of consequences in the Chesapeake Bay Program and in larger USGS land cover programs. More robust analytical approaches to the causes and consequences of ecosystem decline in the Chesapeake Bay watershed are needed in order to develop a more comprehensive understanding of the ecological stressors and likely methods for successful ecosystem restoration.

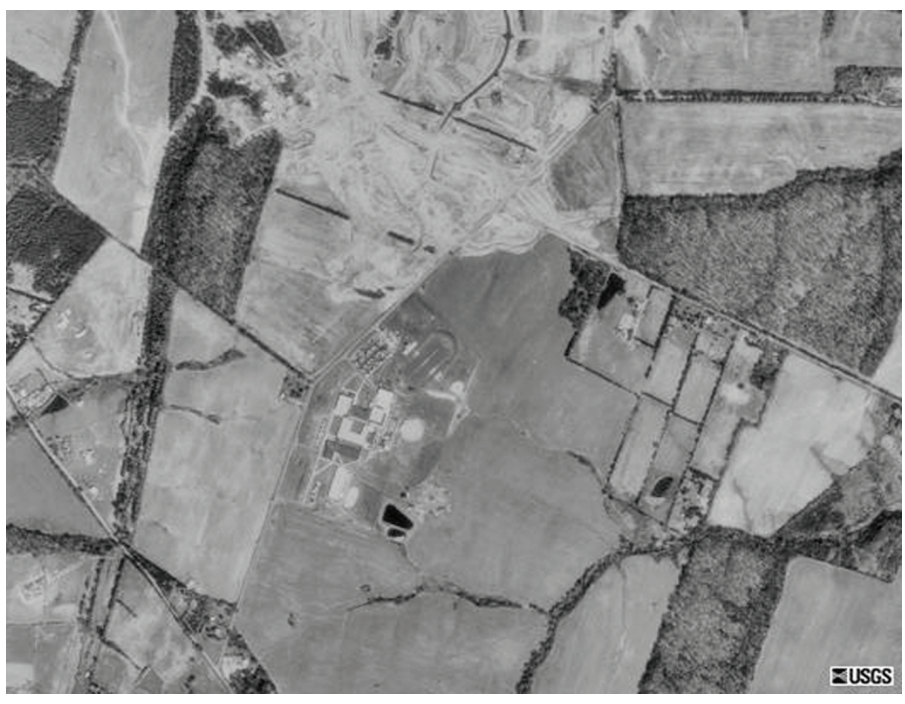

1988

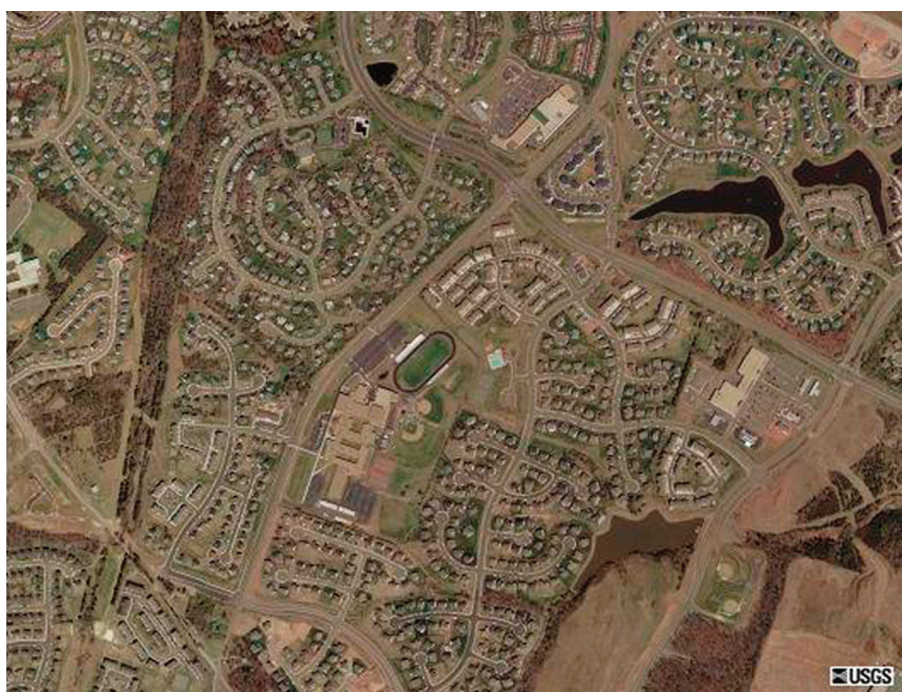

2002

Figure 2. Aerial images of the Ashburn area in Loudoun County, Va., showing an example of the rapid changes in land use in the Chesapeake Bay watershed. The 1988 image is from U.S. Geological Survey; the 2002 aerial image (C2002 Commonwealth of Virginia) is from The National Map (http://nationalmap.gov). 


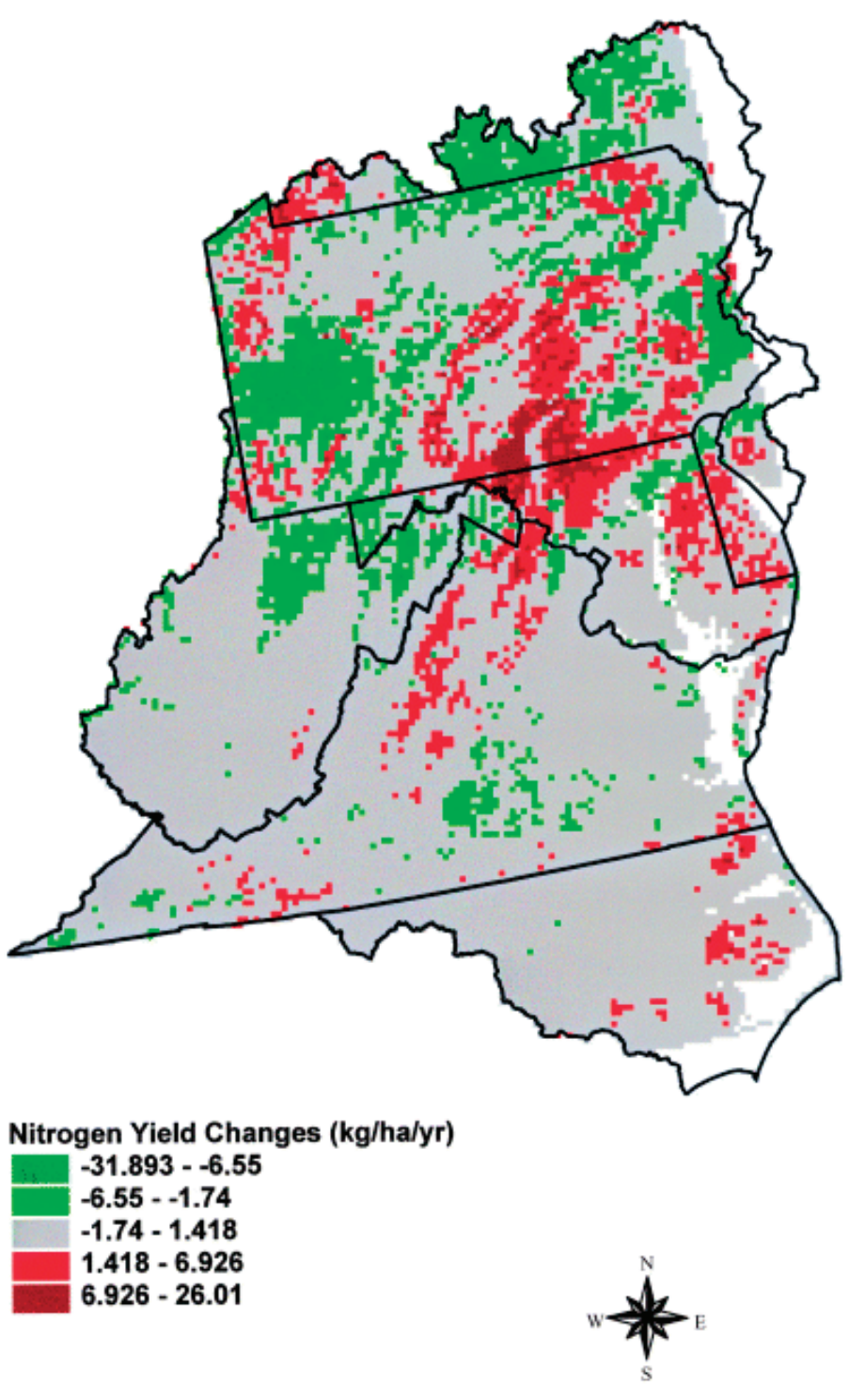

Figure 3. Changes in annual nitrogen loading in the Mid-Atlantic region from 1970 to 1990 based on a landscape indicator approach. From Jones, Neale, Wade, and others (2001). kg/ha/yr, kilograms per hectare per year.

\section{Objectives and Approach}

The objective of the planned USGS research is to develop and test a spatial analysis methodology to identify and articulate the consequences of land cover change in the Chesapeake Bay watershed from 1970 to 2000 . To do this, we will use a general landscape indicator model framework that utilizes synoptic land cover data to compute landscape metrics and landscape indicators as independent variables to explain their spatial relationship with a dependent variable representing an ecological consequence (for example, nutrient and sediment loads). We will modify the landscape model approach based on work by Jones, Neale, Wade, and others (2001) by expanding the historic analysis through the year 2000 and by analyzing high-spatial resolution imagery to articulate the specific land use and land cover changes and potential causal factors that relate to the significant consequence of the ecological change being evaluated.

\section{References Cited}

Jones, K.B., Neale, A.C., Wade, T.G., Wickham, J.D., Cross, C.L., Edmonds, C.M., Loveland, T.R., Nash, M.S., Riitters, K.H., and Smith, E.R., 2001, The consequences of landscape change on ecological resources; An assessment of the United States Mid-Atlantic region, 1973-1993: Ecosystem Health, v. 7, no. 4, p. 229-242.

Jones, K.B., Williams, L.R., Pitchford, A.M., Slonecker, E.T., Wickham, J.D., O’Neill, R.V., Garofalo, D., Riitters, K.H., Kepner, W.G., and Goodman, I.A., 2000, A national assessment of landscape change and impacts to aquatic resources; A 10-year research strategy for the landscape sciences program: U.S. Environmental Protection Agency [Report] EPA/600/R-00/001, 29 p.

McMahon, Gerard, Benjamin, S.P., Clarke, Keith, Findley, J.E., Fisher, R.N., Graf, W.L., Gundersen, L.C., Jones, J.W., Loveland, T.R., Roth, K.S., Usery, E.L., and Wood, N.J., 2005, Geography for a changing world; A science strategy for the geographic research of the U.S. Geological Survey, 2005-2015: U.S. Geological Survey Circular 1281, 54 p. (Also available online at http://geography.usgs.gov/documents/USGSGeographySciencePlan.pdf.)

O’Neill, R.V., Hunsaker, C.T., Jones, K.B., Riitters, K.H., Wickham, J.D., Schwartz, P.M., Goodman, I.A., Jackson, B.L., and Baillargeon, W.S., 1997, Monitoring environmental quality at the landscape scale: Bioscience, v. 47, no. 8, p. 513-519.

Phillips, S.W., 2005, U.S. Geological Survey Chesapeake Bay science plan, 2006-2011: U.S. Geological Survey Open-File Report 2005-1440, 52 p. (Also available online at $h t t p: / /$ chesapeake.usgs.gov/USGSChesapeakeBayplan.pdf.)

Pitchford, A.M., Denver, J.M., Olsen, A.R., Ator, S.W., Cormier, S.M., Nash, M.S., and Mehaffey, M.H., 2000, Testing landscape indicators for stream condition related to pesticides and nutrients; Landscape Indicators for Pesticides Study for Mid-Atlantic Coastal Streams (LIPS-MACS): U.S. Environmental Protection Agency [Report] EPA/600/R-00/087, 87 p.

\section{For further information, please contact:}

Terrence Slonecker

Eastern Geographic Science Center

U.S. Geological Survey

521 National Center, 12201 Sunrise Valley Drive

Reston, VA 20192

Telephone: 703-648-4289

E-mail: tslonecker@usgs.gov

\section{By Terrence Slonecker}

